\title{
Nota pessoal
}

JOÃO ROBERTO FARIA

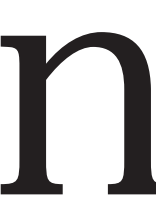

ão me é fácil escrever este depoimento sobre Decio de Almeida Prado, apenas duas semanas depois de sua morte. Ainda estou muito triste e comovido. Os amigos comuns sabem o quanto éramos ligados um ao outro, o quanto eu o admirava e o quanto senti a sua perda, ainda mais porque estou fora do Brasil, a trabalho, por um semestre. A última vez que estivemos juntos foi no final de dezembro, quando o visitei para me despedir. Conversamos sobre o seu estado de saúde e eu não me dei conta de que os problemas do coração que o afligiam fossem tão graves. Esperava reencontrá-loem junho e já havia inclusive comprado um livro para levar-lhe de presente e que certamente ele iria apreciar: The Masks of Othello, de Marvin Rosenberg, uma história das principais interpretações do papel de Otelo, desde o século XVII até hoje. A notícia de sua morte colheu-me de surpresa. Longe, não tive o conforto dos amigos e não pude dar-lhe o último adeus.

Não quero escrever sobre a obra crítica de Decio, cuja importância é unanimemente reconhecida em nosso meio cultural. Já fiz isso em várias oportunidades, estrevistando-o e comentando seus livros em resenhas e ensaios. Para o leitor interessado em conhecer um pouco mais da vida e da obra desse grande intelectual brasileiro, recomendo a leitura do livro Décio de Almeida Prado: um Homem de Teatro, publicadoem 1997 pela Editora da Universidade de São Paulo e organizado por mim, Flávio Aguiar e Vilma Arêas.

Neste momento quero apenas me lem- brar de nossa convivência de quase duas décadas e exprimir o sentimento de gratidão que guardo comigo, por ter aprendido tanto com ele.

Duas imagens de Decio vão ficar gravadas para sempre na minha memória: a do amigo e a do professor e estudioso apaixonado do teatro brasileiro, imagens que por vezes se confundiam nos encontros que mantínhamos regularmente em sua casa, uma ou duas vezes por mês. Explico-me: Decio foi meu orientador no mestrado, acompanhou a redação das minhas teses de doutorado e livre-docência e leu praticamente todos os textos críticos que escrevi e publiquei nos últimos quinze anos. Tê-lo como interlocutor foi um privilégio. Suas observações críticas, sugestões, explanações e correções contribuíram de maneira decisiva para a minha formação e para o conhecimento que tenho hoje do teatro brasileiro. Quanta generosidade em sua disposição para o diálogo com o aprendiz! Quanto do seu tempo foi gasto com a leitura anotada e comentada dos textos que escrevi! Além desse privilégio, tive outro ainda mais enriquecedor: acompanhar de perto a redação de seus últimos seis ou sete livros. Brincando, ele me dizia que havia passado por tantas reformas ortográficas da língua portuguesa que não sabia mais onde pôr ou tirar acento. Assim, ele me passava os capítulos ou partes dos livros que estava escrevendo, que eu então revisava com um prazer intelectual indiscritível e uma ponta de orgulho por merecer tal distinção. Não é preciso dizer o quanto aprendi com essas leituras e as conversas posteriores, no que
JOÃO ROBERTO

FARIA é professor do Departamento de Letras Clássicas e Vernáculas da FFLCH-USP. 
diz respeito ao teatro brasileiro e à metodologia para melhor estudá-lo.

Creio que o interesse comum pelo século XIX e pela historiografia do teatro brasileiro nos aproximou ainda mais. Decio conhecia como ninguém o período da formação do nosso teatro, como demonstram os dois livros que escreveu sobre o ator João Caetano, os ensaios dedicados ou ao período anterior ao nosso romantismo ou a Gonçalves Dias, e o livro sobre o drama romântico. Há aí páginas primorosas de crítica e interpretação, que revelam tanto a sensibilidade do analista, quanto a vocação do pesquisador e historiador. Pois enquanto ele se dedicava ao estudo da dramaturgia romântica, estimulava-me a pesquisar o período realista, trabalho que efetivamente realizei e que, para minha felicidade, o deixou satisfeito, por estabelecer a seqüência histórica em relação ao que vinha escrevendo.

Mas o século XIX ainda merecia estudos específicos. Decio debruçou-se sobre o gênero cômico e, assim como havia feito com o drama romântico, deu-nos um ensaio notável sobre os principais autores e as três formas do teatro musicado-a opereta, a mágica e a revista de ano - que divertiram os nossos antepassados entre 1865 e 1908 , data da morte de Artur Azevedo. Como se sabe, o predomínio do teatro cômico e musicado foi absoluto naqueles anos, principalmente no Rio de Janeiro, capital do Império e da República. Nessa altura, eu estava tentando localizar nos jornais do Rio de Janeiro informações a respeito de possíveis encenações de peças naturalistas, brasileiras ou estrangeiras, insatisfeito que estava com o pouco que se sabia sobre o assunto. Decio incentivou-me e acompanhou com interesse essa investigação, cujos resultados incorporei em minha tese de livre-docência.

Nosso diálogo em torno do teatro brasileiro do século XIX foi intenso. Passamos muitas tardes conversando sobre autores e peças pouco conhecidos, trocando idéias e informações. Ao longo dos anos, nossos encontros amiudaram-se e ficamos amigos. As conversas já não eram apenas sobre teatro brasileiro, do passado ou do presente, mas também sobre literatura de um modo geral, futebol, xadrez, ópera, a velha São Paulo, política, história, pessoas, lugares e muitas outras coisas. Decio era um causeur extraordinário e gostava de contar casos engraçados ou curiosidades e anedotas que envolviam ele mesmo ou companheiros da sua geração, artistas do meio teatral e escritores. $\mathrm{O}$ chá às quatro da tarde, por hábito e depois por necessidade de se alimentar e controlar a diabetes, era sempre um momento descontraído, no qual dávamos boas risadas, até mesmo permitindo-nos falar um pouco mal da vida alheia, que ninguém é de ferro. Essa imagem do amigo brincalhão e bem-humorado, rápido no dito espirituoso e certeiro no uso da fina ironia - armas da inteligência, como se sabe - é a que me vem à mente neste momento em que escrevo. Porque, feitas as contas, não colhi apenas lições de teatro em nossa convivência, mas sobretudo lições de vida. Afinal, o intelectual generoso, que me franqueou a excelente biblioteca e me orientou nos trabalhos acadêmicos, era uma extensão do homem, do ser humano admirável que foi Decio de Almeida Prado.

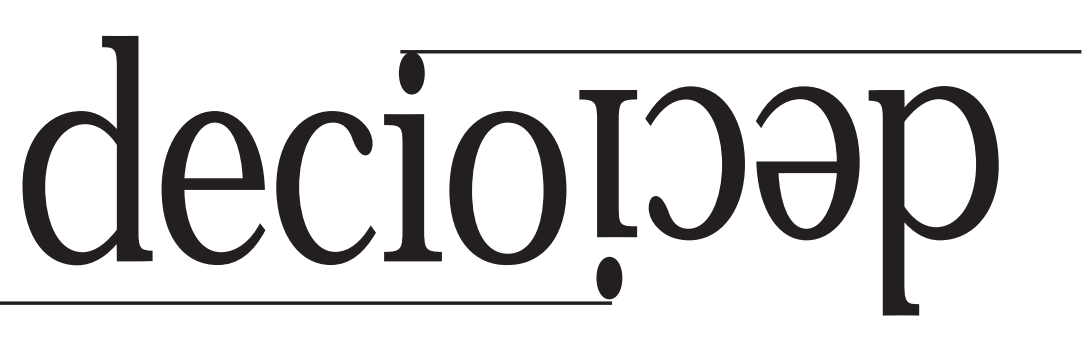

